\title{
Modern trends in the structure of Foreign Direct Investment (FDI) in the world economy
}

\author{
Alex Pomelnikov \\ Gilbert J. Werema \\ College of Business, \\ Texas Woman's University \\ 304 Administration Dr. Denton, TX 76204, USA
}

\begin{abstract}
Due to changes in the structure and trends of foreign direct investment (FDI), the development of the world economy has undergone significant differences over the past six years. Prior to 2011, FDI was primarily focused on the service sector (representing 40\% of total world FDI) according to United Nations Conference on Trade and Development (UNCTAD) report, however, the current trend has changed. This article is devoted to the changes that occurred between 2011 and 2016 in the structure of FDI to create these differences and the potential long-term impact to the development of the world economy. To analyze these objectives data was collected from the World Bank, International Monetary Fund-Balance of Payment database, and UNCTAD, FDI/Multinational Enterprise Database.
\end{abstract}

JEL Classification: F1, F2, F3, F31, F32

Keywords:Foreign direct investments (FDI), Global FDI flows, World economy, Transnational corporations (TNCs), Megaregional groups, Geopolitical risks, Developing countries, Economies in transition, Cross-border transactions, Emerging markets Global economy

\section{Inroduction}

Attracting foreign capital is among the most important factors in the development of market relations in the world economy. Migration of capital has led to an expansion of the internationalization of economic life and unveiled the blossoming global economy, which has manifested itself in the mutual flow of capital between industrialized countries.

Large companies in industrially-developed nations are becoming increasingly transnational, moving beyond national borders. The formation of large multinational companies, which have divisions operating in different countries around the world, leads to an acceleration of international specialization and cooperation. The formation of transnational companies and resulting mutual movement of capital is the most important factor and catalyst for expanding economic interdependence of countries in the world economy and in turn, directly impacts the creation of a new world economic order.

Attracting foreign investment can help increase the output and expand export of certain types of products allowing them to become competitive in external markets. Cooperation with foreign partners can also have a positive impact developing foreign marketing experience and training personnel.Foreign capital does not only provide additional material and monetary resources, but also is a serious catalyst for the development of market relations within the country. Further development of joint business activities can aid in the fight against monopolism by creating an enterprise with competing structures that allows them to resist the dictates of the established monopolies.

Foreign direct investment stimulates employment and production growth, contributes to the revitalization of the interrelationships in all economic sectors and encourages the activation of driving forces, which will ensure resolution of the economic and social contradictions that have accumulated within the society. In order to understand the possibility of obtaining this profit, it is necessary to recognize the characteristics of each group of factors that induce FDI: marketing factors, trade restrictions, cost factors and investment climate.

\subsection{Factors That Induce Fdi}

Market factors. 1) the size of the market, 2) the growth of the market, 3) the desire to retain part of the market, 4) the desire to succeed in the export of the parent company, 5) the need to maintain close contact with customers, 6) dissatisfaction with the existing state of the market, 7) the export base, 8) Following the customers, 9) following the competition. Growth of FDI is directly impacted by marketing factors. TNCs need to expand their market to maintain or increase their sales while even a sufficiently large domestic market sets the limits to growth. Limited product diversification and the size of the domestic market makes it necessary to geographically diversify production-the organization of production abroad, the acquisition of foreign firms and the establishment of control over them. 
Trade restrictions. 1) Trade barriers, 2) local buyers prefer domestic products. FDI allows firms to bypass trade barriers and function abroad as local firms that are not subject to customs duties, payments or other import restrictions. Nationalistic tendencies or consequences of existing cultural characteristics can add non-governmental barriers. Some buyers prefer to consume local goods and services. Moreover, often local buyers want to buy goods and services from those who they trust, i.e. domestic producers. To combat some of these issues, the firm may elect to establish a plant in the consumer country to create jobs, improve consumer relations and ultimately produce a positive impression on product quality as a local or domestic brand.

Cost factors. 1) the desire to be closer to the source of supply, 2) the availability of labor resources, 3) the availability of raw materials, 4) the availability of capital and technology, 5) low cost of labor, 6) low cost of other production costs, 7) low transportation costs, 8) financial and other incentives from the government, 9) more favorable price levels. Serviced markets are at a considerable disadvantage and limited by high tariff barriers, which create a lot of obstacles to exporters in foreign markets. Many of the industrial TNCs base their production abroad to obtain cost advantages in labor and raw materials. For example, a German worker in the manufacturing industry costs four (4) times more than the Taiwanese, nine (9)times more than Brazilian and 54 times more than the Russian. As a result, most American subsidiaries supply their US parent companies with low cost factors and components.

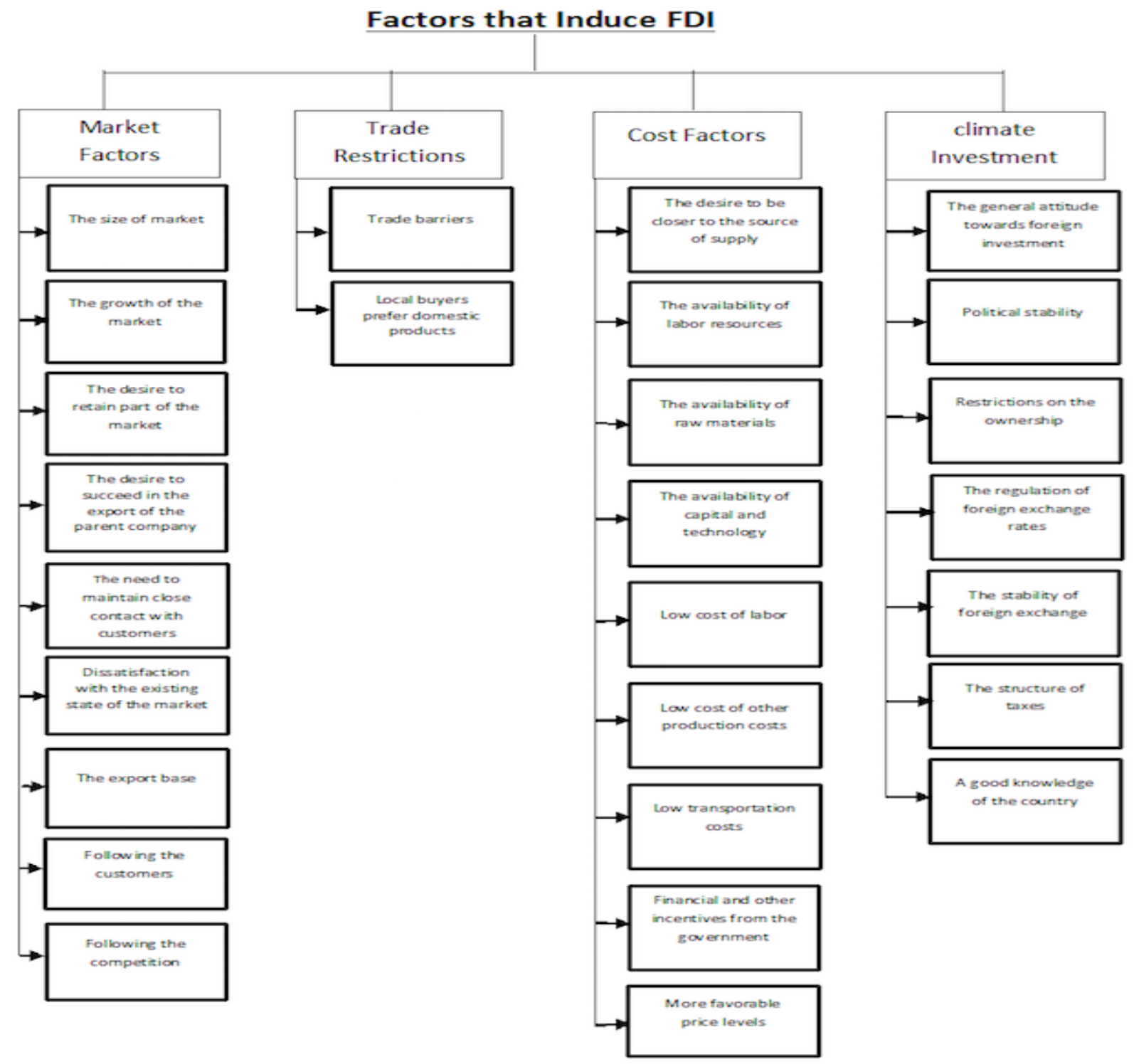

Foreign direct investment is realized not only horizontally, i.e. firms that buy or establish similar firms abroad, buy also vertically. Some firms see the attractiveness of FDI in how it becomes possible to improve the reliability of sources of supply of raw materials and other intermediate products (semi-finished products). Vertical integration increases the reliability of supply and can lead to a reduction in operating costs and provide control over trade flows across borders in a complex global distribution system. 
Investment climate. 1) the general attitude towards foreign investment, 2) political stability, 3) restrictions on the ownership, 4) the regulation of foreign exchange rates, 5) the stability of foreign exchange, 6) the structure of taxes, 7) a good knowledge of the country.

FDI by definition allows for control over the activities of the enterprise. However, control may be useless if there are unfavorable environmental conditions, even if the firm fully (100\%) owns the branch. The reality of ensuring control, and hence the profitability of FDI, depends on the availability of a positive investment climate within the country. In other words, the political, economic, legal, social and living conditions are critical in determining the degree of investment risk and their profitability.

The general attitude of the world towards foreign investment and their subsequent development can be defined as ambivalent (dual). Although the benefits of FDI in the short term are recognized, almost all countries limit foreign ownership in key sectors of the economy to avoid loss of control over national economic resources and the sovereignty of the country. Discrimination against FDI is also realized in the form of tax increases, price control or measures directed personally at foreign firms such as partial nationalization, local legislation, limiting of transfer of money (payments), export rules and restrictions on emigration of labor. Investment climate is also determined by currency risks, which is usually expressed in the occurrence of risks associated with the transfer and circulation of foreign currency.

General. 1) The expectation of high profits, 2) others. These FDI factors are specified in the development of investment policy through a system that includes approximately 340 indicators and more than 100 expert assessments in the economic, legal, technical, social and other fields. The analytical data includes ten (10) primary factors that assess the potential of a country to host FDI or the so-called competitive potential of the country. These factors include:

- The dynamics of the economy and economic potential;

- Industry production capacity;

- market dynamics;

- Financial assistance from the government;

- Human capital;

- The prestige of the state;

- Availability of raw materials;

- Focus on the foreign market (export opportunities);

- Innovation potential;

- Social stability.

Each of the ten (10) factors include a system of specific indicators. For example, in assessing human capital, Swiss experts proposed the use of 36 indicators, including: population size and its dynamics, general unemployment rate, migration of the labor force as a whole including the highly skilled, level of professional training, motivation of hired workers and their mobility, management and its professional adaptation, wage level, public spending on education per capita, level of labor with higher education, release of periodicals, health system, etc.

In practice, most decisions about foreign direct investment are based on a variety of motivations taking into account numerous factors. Political motives for investing are rarely separated from economic ones. Based on the date of expert assessments, the following countries have the most attractive conditions for FDI: Canada, Germany, Switzerland and the Asia-Pacific New Industrial Countries (NIS). (2)

\section{Literature Review}

Foreign Direct Investment has been shown to play an important role in achieving rapid economic growth and development of a nation. Many research studies have been conducted to explore the factors that lead to a greater amount of FDI.

Hummels and Stern(1994) found technology, labor skills and infrastructure were the major determinants of FDI and are also important in explaining the trend and pattern of FDI inflows and outflows. Asiedu, E. (2006) identified large local markets, natural resource endowments, good infrastructure, low inflation, an efficient legal system and a good investment as the determinants that increased FDI. Blonigen, B. (2011) found that cultural distance factors, parentcountry per capita GDP, relative labor endowments and regional bilateral trade agreements, government expenditure, gross fixed capital formation, gross domestic product, inflation rate, exchange rate. Flora, A. \& Agrawal, G. (2014) found that market size, natural resources, skilled human capital, trade openness, low interest rates and labor cost to be the main determinants of FDI. 
Wang \& Swain (1995) found low cost labor to be an important factor in attracting FDI inflows. The establishment of property rights, in particular intellectual property rights, is crucial to attract high technology FDI (Smarzynska, 1999). Laura Alfaro (2003) found that FDI flows into the different sectors of the economy such as primary, manufacturing, and services exert different effects on economic growth. FDI inflows into the primary segment have a negative consequence on growth, whereas FDI inflows into the manufacturing sector a positive one. Evidence from the foreign investments in the service sector was found to be ambiguous.

\section{Research Methodology And Objectives Of Study}

The present research was focused on the changes in the structure and trends in Foreign Direct Investment (FDI) and changes the world economy has undergone in the las decade. The study starts by identifying the characteristics of each group of factors that induce FDI: Market factors, Trade Restrictions, Cost Factors, and Investment Climate. To analyze these objectives data was collected from the World Bank, International Monetary Fund-Balance of Payment database, and UNCTAD, FDI/Multinational Enterprise Database. This research article is descriptive in nature.

\subsection{Fdi Trends}

We have identified three (3) main trends in the structure of FDI.

1. High dynamics of global FDI recovery

Foreign direct investment (FDI) flows between 2009 and 2011 increased by $46.15 \%$ to 2.28 trillion in 2011, the highest level since the global financial and economic crisis of 2008-2009. The main factor of such global recovery was the increase in international mergers and acquisitions (M\&A) to 721 billion dollars as opposed to 432 billion dollars in 2014. Investments in new projects totaled 766 billion dollars, which included growth in FDI from a change in corporate configuration. These deals are often associated with large changes in the balance of payments with minor changes in actual operations. If you ignore these major changes in the configuration of corporations, the growth of global FDI flows will be more moderateapproximately $15 \%$.

2. Doubling the flow of FDI into developed countries and achieving a new high inflows to developing countries.

The inflow of FDI to the developed countries almost doubled, reaching 962 billion dollars. As a result, in the structure of global FDI, developed countries again prevailed, 55\% compared to $41 \%$ in 2014. High growth in the import of FDI was recorded in Europe. In the United States, FDI increased almost fourfold, albeit from a low level compared to the levels prior to 2014 .

Figure 1

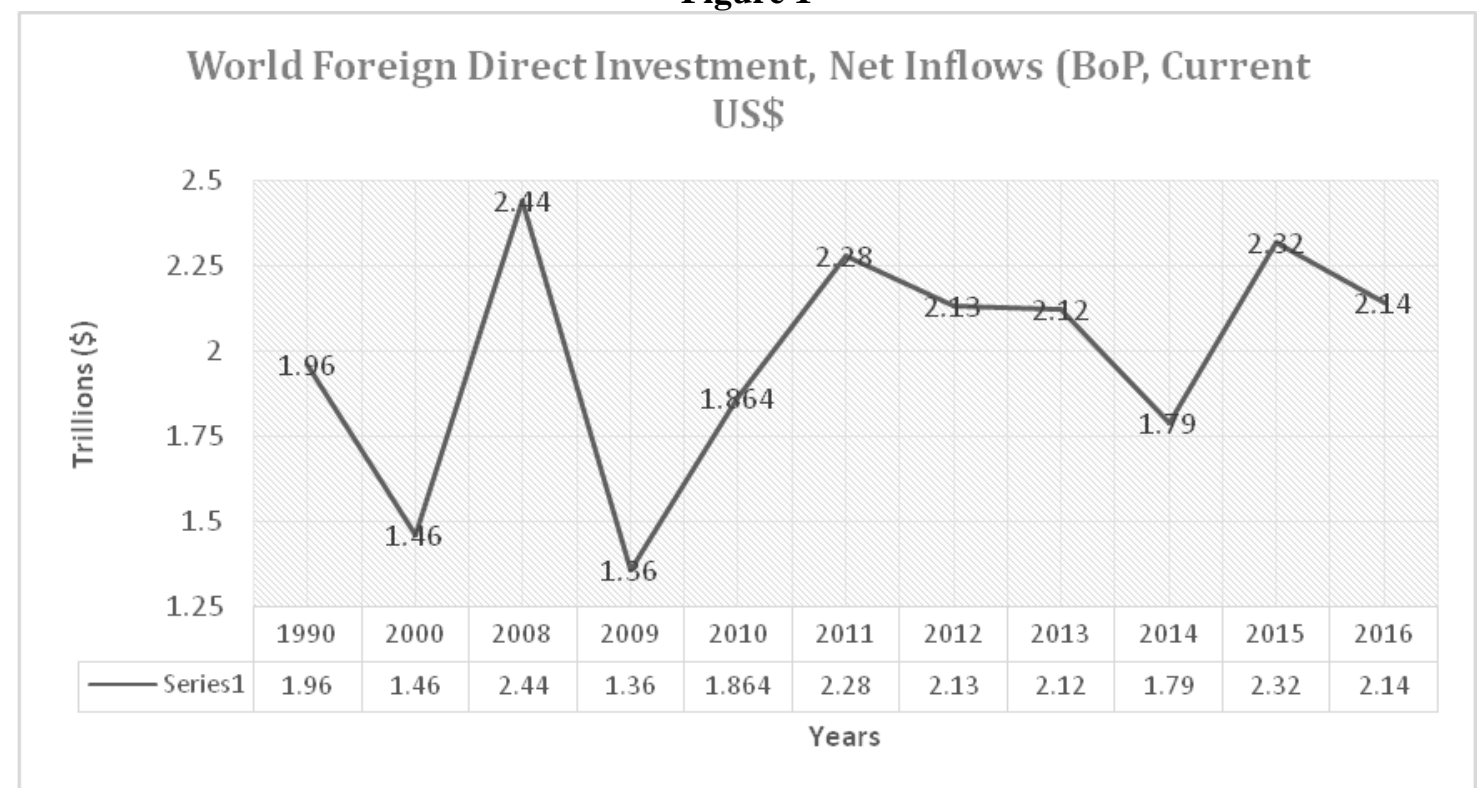

Source: International Monetary Fund, Balance of Payments database, supplemented by data from the United Nations Conference on Trade and Development and official national sources.

In developing countries, a new high inflow of FDI was reached in 2015, 765 billion dollars, which was 9\% higher than in 2014. Developing countries in Asia, where FDI exceeded half a trillion dollars, remained the world's largest recipient of FDI. Inflow to Africa, Latin America and the Caribbean stalled. Developing countries still account for half of the ten (10) countries with the largest inflow of FDI. Export of FDI from developed countries jumped by $33 \%$ to 1.1 trillion dollars. 
Despite such growth, the increase in their export of FDI remains $40 \%$ below the 2007 peak. Taking out 576 billion dollars, Europe has become the largest investor region in the world. FDI of the MNP of North America remained close to the level of 2014.

3. Growth of FDI accommodation in the manufacturing sector with a reduction in the primary sector. Within the primary sector, FDI declined, while it increased in the manufacturing industry.

In 2015, a wave of transactions raised the share of manufacturing industry in the international S\&P over 50\%. FDI in the primary sector decreased due to the reduction of planned investment in response to a decrease in prices for raw materials as well as a sharp reduction in the reinvestment of revenue in conditions of contraction of the rate of return. Services still account for over $60 \%$ of global FDI.

\begin{tabular}{|l|l|l|l|l|l|l|}
\hline \multicolumn{9}{|c|}{ Table 1. Sectoral distribution of FDI projects } & \multicolumn{3}{l|}{ (Billions of dollars and per cent) } \\
\hline Year & & Value & & & Share & \\
\hline & Primary & Manufacturing & Services & Primary & $\begin{array}{l}\text { Manufacturin } \\
\text { g }\end{array}$ & Services \\
\hline Average 2005-2007 & 130 & 670 & 820 & 8 & 41 & 50 \\
\hline 2008 & 230 & 980 & 1130 & 10 & 42 & 48 \\
\hline 2009 & 170 & 510 & 630 & 13 & 39 & 49 \\
\hline 2010 & 140 & 620 & 490 & 11 & 50 & 39 \\
\hline 2011 & 200 & 660 & 570 & 14 & 46 & 40 \\
\hline \multicolumn{2}{l}{ Source: UNCTAD, World Investment Report 2012. } \\
\hline
\end{tabular}

Countries within Asia, marked growth the inflow of FDI grew by $16 \%$ to 541 billion dollars-a new record high. This significant growth was result of the high performance of the countries of East and South Asia. It is expected that in 2016 the inflow of FDI will slow down and return to the level of 2014. Export (outflow) from the region declined by about 17\%, to 332 billion dollars-the first decline since 2012 .

The inflow of FDI into Latin America and the Caribbean, excluding offshore financial centers, remained at the previous level of $\$ 168$ billion in 2015. In South America, the growth in FDI was held back due to the slowdown in domestic demand growth and the deterioration in the "terms of trade" caused by falling raw materials (commodity) prices. Conversely, in Central America, in 2015, there was a positive trend due to the growth in FDI in the manufacturing industry. In 2016, the inflow of FDI into the region may slow down due to the still complex macroeconomic conditions of reproduction.

In countries with economies in transition, FDI inflows continued to decline to levels from a decade ago as a result of a combination of lower raw materials (commodity) prices, reducing conditions in the domestic markets and the impact of the restrictive measures and geopolitical tensions. The outflow of FDI from this region also slowed down due to more limited access to international capital markets. After the downturn in 2015, FDI inflows into transition economies are expected to show moderate growth.

After three consecutive years of declining FDI in developed countries, inflows rose sharply reaching its highest level since 2007. The main factor in this was the exceptionally high amount of international M\&A transactions in the developed countries. The announced investments in new projects also remained high. The export of FDI of this group rose sharply. The recovery of FDI the export (outflow) is unlikely to continue in 2016 in light of slowing growth in some major developed countries by the end of 2015.

The inflow of FDI into a group of countries with a structurally weak and vulnerable economy showed a modest $2 \%$ growth, reaching $\$ 56$ billion. The inflow into the least developed countries (LDCs) jumped by one third to $\$ 35$ billion. Landlocked developing countries (LLDCs) and Small Island developing States (SIDS) saw a decline in inflows of FDI respectively by $18 \%$ and $32 \%$. Divergent trends are also reflected in the FDI forecasts for them for 2016. If the LLDCs are expected to increase FDI inflows with LDCs and SIDS combined, projected FDI imports are still low.

\section{Conclusions}

In today's economy, the main directions of investment flows are foreign direct investment (FDI) in developed countries. In the future, FDI flows are expected to decline by 10-15\% in 2016, reflecting the vulnerability of the global economy, persistently low dynamics of aggregate demand and sluggish growth in some countries specifically exporters of raw materials, effective policies to limit tax inversion deals (transactions) and reduced multiple rates of return (MRR) profits. In the mid-term, the renewal of global FDI flows is expected to increase in 2017 and will exceed the level of 1.8 trillion in 2018 as a result of expected acceleration of global growth. These features must be considered when making decisions about the implementation of global investment in various sectors of the world economy. 


\section{References}

Asiedu, E. (2006). Foreign direct investment in Africa: The role of natural resources, market size, $t$ government policy, institutions and political instability. The World Economy, 29 (1), 63-77.

Blonigen, Bruce and Piger, Jeremy, (2011), Determinants of Foreign Direct Investment, No 16704, NBER Working Papers, National Bureau of Economic Research, Inc.

Flora, P \& Agrawal, G. (2014). Foreign direct investment (FDI) and economic growth among relationship highest FDI recipient asian economies: A panel data analysis. International Business Management. 8. 126-132.

Hummels, D.L. and Stern, R. (1994). Evolving Patterns of North American Merchandise Trade and Foreign Direct Investment, 1960 - 1990, The World Economy, January, pg 5-29. http://dx.doi.org/10.1111/j.14679701.1994.tb00806

Laura Alfaro (2003). Foreign Direct Investment and Growth: Does the Sector Matter?, Working Paper Harvard Business School.

Smarzynska, B.K. (1999). Composition of Foreign Direct Investment and Protection Intellectual Property Rights in Transition Economies, unpublished working paper, New Haven: YaleUniversity.

Wang, Z. Q. \& Swain, N.J. (1995). The determinants of foreign direct investment intransforming economies: empirical evidence from Hungary and china. Weltwirtsch Arch131(2):359-82.Science Library of dissertations and abstracts disser Cat http://www.dissercat.com/content/prayamye-inostrannye-investitsii-v-ekonomike-rossiiskoifederatsii\#ixzz4VAkcuXad

International Monetary Fund, Balance of Payments database

(https://data.worldbank.org/indicator/BX.KLT.DINV.CD.WD) UNCTAD, FDI/ Multinational Enterprise Database (www.unctad.org/fdistatistics)

P. Dornbusch, S. Fischer, \& R. Starz, Macroeconomics. New York. McGraw Hill.

P.R. Krugman, M. Obstfeld. International Economics. Theory and politics. New York. McGraw Hill 